\title{
THE DEPLOYMENT AND APPLICATION OF SPANISH CULTURAL POLICY DURING THE 20TH CENTURY
}

\author{
Katerina Papaioannou \\ University of Patras, GREECE, papaioannou.kat@gmail.com
}

\begin{abstract}
In this paper, we provide an analysis of the cultural policy of Spain in its recent history. Starting with a historical and cultural panorama of Spain in the 20th century, we investigate whether Spain reached a conceptual understanding of the power of its culture and whether it subsequently established and implemented a cultural strategy in a truly eventful period of its history. At the beginning of the 20th century, with its wounds still open from the defeat suffered by the United States in 1898, Spain was considered a "dead country". Herein, we discuss how historical circumstances influenced the cultural setting in Spain, how Spain reacted and to which extent the investment in culture helped in the "renaissance" of Spain. We address the role of educational and scientific progress and examine whether cultural development can mobilize people and set the foundations of a new collective conscience. We also discuss whether preservation and exploitation of cultural elements introduces a barrier to progress and modernization.

As part of the development of a cultural strategy, Spain used the American reference as an alternative space for cultural and economic confirmation and expansion. The American dimension was perceived as an incentive for modernization and reform, which, in this case, was a bet for the future without abandoning the past; it was also considered as a place where common elements in the reform process could be found, a place of global, international value which could further support the European character Spain planned to acquire. To obtain this objective, Spain had to revive common links and re-establish a common Spanish consciousness. America formed an external compensating factor, which, properly exploited, could help Spain regain its role on the international stage. To this aim, religion and language were important, unifying factors. In this context, we present our analysis on how Spain efficiently managed this important legacy and how it successfully exploited its cultural assets in order to establish a cultural strategy.
\end{abstract}

Keywords: Spain, cultural policy, culture and history.

\section{INTRODUCTION}

Spain, the western European country of the Mediterranean, with a historically intense imperialistic policy and clear and strong cultural stigma which strongly overshadowed extremely important civilizations in human history, is one of the key-countries for the understanding of the concept of having a national cultural strategy. 
In the course of human history, Spain has been a meeting point of different cultures. It was conquered but it also conquered other peoples, having strongly exploited its cultural power for the realization of its imperialistic objectives. The formation of cultural strategy is clearly observed early in Spanish history and it constitutes one of the most powerful means which supported the emergence of Spain to a major colonial power. This role of Spain was permanently overturned in the late 19th century after its defeat in the SpanishAmerican war of 1898 . The beginning of the 20th century finds Spain irreparably wounded from a political, social, and economic point of view and in a highly tensed internal and external situation.

Despite several adventures Spain went through, the first third of the 20th century was one of the peak periods for Spanish culture. This particular period was part of the so-called Silver Age (Edad de Plata) due to the activity of great writers, artists and researchers of that time, who enjoyed national and international recognition. These brilliant groups of intellectuals were classified into literary generations mainly according to period of their activity.

The rest of the paper is structured as follows. In Section 2, we present the cultural policy of Spain during the period that preceded the Civil War. In Section 3, we address and describe the cultural policy is Spain in the context of Franco regime during the $2^{\text {nd }}$ World ar. Concluding remarks are presented in Section 4.

\section{CULTURAL POLICY OF SPAIN UNTIL THE CIVIL WAR}

Since the early 20th century, Europe and modernization were closely related concepts, according to the most advanced Spanish culture media whose desire to approach parameters of developed European countries was clearly evident. It is indicative that since the second half of the 19th century, the Free Education Institution (Institución Libre de Enseñanza) appeared in academic circles. However, in the 20th century the government took the initiative to promote scientific and cultural convergence with Europe.

For most intellectuals of that time, close relations of Spain with the rest of Europe were crucial for progress and modernization of the country. However, the American reference played an equally important role. For overcoming its collapse, Spain needed America as an alternative space for confirmation and expansion, mainly cultural but also economic. The ultimate decision of Spain to acquire a European character presupposed accepting a position entirely subject to the interests of large continental hegemonic forces. The American dimension was perceived as an incentive for modernization, which, in this case, was associated with vitality and natural resources still untapped in the region. It was a bet for moving on to the future without abandoning the past, a place where common ground for the reform process could be found, a place considered as an important asset at supranational level which could add value to the desired European character (Gómez-Escalonilla, 2002).

For this goal to be feasible, common links and a shared Spanish conscience had to be restored. Intellectuals should work towards this direction, favoring the creation of a feeling of cooperation within societies; a feeling which would diminish consequences resulted from the indifference of governments. On the other hand, assuming that history hammers the spirit of citizens, America was invaluable for building a collective memory not compromised by the failure image, but based on the positive assimilation of common historical experience, which would open up new avenues for dialogue in the future and would compose the answer to the negative stereotype about anything "Spanish". The struggle against the "black legend» ("leyenda negra"), the defense of the Spanish colonization in a global and comparative dimension was particularly important in this confrontation with the past (Pérez Garzón, 2000). America was an external compensating factor which, properly handled, could contribute to making Spain more than a peripheral and relatively isolated country within the European scene. The desire of Spain to become the representative of a much wider territorial region with increased potential and resources remain active, although weakened, as a platform to achieve greater international influence. Spanish turn to America basically refers to nations that were part of its empire in earlier centuries. The US was out of this circle of countries supported by common history, common language and common religion. However, the North American nation was not excluded from this opening of horizons during the first decades of the 20th century. Its contribution was mainly realistic and absolutely influential for science and technology (Rodríguez, 1993).

Both trends, both European and American, tended to be a little closer after the appearance of the first bodies engaged in the promotion of Spanish culture abroad. In Spain, the proposal for the creation of an original structure within the Ministry of State (Ministerio de Estado) to deal with such issues, started again from circles of intellectuals who had supported the openness of the country in the first place. The new potential Spain developed from the beginning of the century regarding cultural issues, along with the value of its historical heritage and the significant spreading of the Spanish language in the world, provided highly important resources for the external recovery of the country (Gómez- Escalonilla, 1992). 
The rapid rise of Spanism and the spreading of the Spanish language created an increased demand for educators abroad. The answer to this demand was firstly the organization of courses on the Spanish language and literature for foreign teachers and students offered by researchers of the Centre for Historical Studies (Centro de Estudios Históricos, CEH) since 1912. Towards the same direction, Spanish teachers were sent to various European centers, USA and Far East and the Institute of Spain in New York was established, which promoted the teaching of Spanish language and provided academic personnel to US universities.

Spain planned to adopt a model similar to that developed by France. Spain gradually developed an original external cultural strategy model and promoted the establishment of an official body responsible for its application. This body had a modest organizational structure, its personnel were carefully selected and even if an official approval was required it was given a large degree of autonomy. The ultimate goal was to structure a domestic and international front in order for the intellectual and scientific revival obtained in the internal of the country to be combined with the cultural development and the strengthening of the Spanish international presence.

The establishment of the dictatorship of Primo de Rivera (Primo de Rivera), immediately after, was accompanied by the resignation of intellectuals who were active at the Spanish Cultural Relations Office (Oficina de Relaciones Culturales Españolas, ORCE). The administration of the Office was conducted by diplomats who redirected all implemented work towards "a plan for cultural expansion and political propaganda". Its primary effect would be directed to modify the existing image of Spain, according to which Spanish people mainly included clergy and matadors where subculture and fanaticism dominated. From the diplomatic perspective, the cultural activity should be subject to a political propaganda utility, as evidenced by the proposal that cultural activity should be included into a single service structure dedicated to promoting cultural and political information (Rodríguez, 2001).

Following the establishment of the Second Republic, the Cultural Affairs Council (Junta de Relaciones Culturales, JRC) adopted a more systematic schedule of work, while they tried to coordinate with the Commission for the extension of Studies and Scientific Research (Ampliación de Estudios e Investigaciones Científicas, JAE) (Gómez-Escalonilla, 1995). The establishment of the democratic regime was supported by the portion of the intellectuals who were in favor of the modernization of the country and its absolutely receptive attitude to innovative currents from abroad. This was reflected in the adoption of a more decisive attitude in the field of cultural policy and its international promotion. In addition, during the same period, cultural ambassadors began to appear abroad, initially in France, US and Argentina. These cultural ambassadors were teachers who were conducting their academic tasks in the center of each particular country together with their diplomatic obligations.

The outbreak of the civil war caused a serious blow and brought about the dismantling of a large part of the infrastructure that had been created. But even more important was the fact that the internal conflict, which ended with the imposition of a dictatorial regime, sentenced to exile or clearance the largest and most active part of academics and scientists who had promoted the creation of the Commission for the extension of Studies and Scientific research (Junta para Ampliación de Estudios e Investigaciones Científicas, JAE) and had participated in the Cultural Relations Council (Junta de Relaciones Culturales, JRC) as convinced supporters of the horizon broadening started some time ago.

\section{THE CULTURAL POLICY OF FRANCO'S SPAIN DURING THE 2ND WORLD WAR}

After the Civil War, Spain was not a country absolutely unaffected by cultural and scientific international trends. The Franco regime neither motivated nor supported any broadening of external contacts in any field; however, it did not make it to establish the ultimate "closure" of the country. In any case, this was something difficult to implement and not really pursued. What Franco regime did attempted was to control external contacts, filter them and direct them towards the achievement of its own objectives. But, beyond serving specific purposes, the established channels of communication led to a flow of information and knowledge that went beyond the strict limits the dictatorship tried to impose (Redondo, 1999). According to those in charge of the Franco regime, all this movement outwards as well as foreign external influence resulted in altering the nature of the country, loss of identity and adoption of streams and trends that led to the dissolution of the national element. However, practically, Franco largely inherited the line of external cultural strategy set by his predecessors, however, under a different ideological perspective (Fernández, Pérez, Comellas, Andrés-Gallego, 1991).

The Civil War halted the progress of Spain towards a cultural synchronization with Europe, as well as the development of a cultural policy towards Latin America and the emerging incipient cooperation with the US. The political regime emerged after the civil war did not consent to the modernization of the country through 
scientific and cultural convergence with Europe, and also despised democratic and liberal values of the US. The administration of the new regime was negative against any external policy since it would destroy the traditional character of the country causing it to lose its universal character. This attitude, however, did not imply a strict cut of cultural contacts with other countries; it rather brought up a redefinition of cultural contacts and a reduction in their intensity, which followed as natural consequences of the priorities set by the new political regime and international circumstances. Key actions, like creation of schools, cultural centers, educator jobs, largely pointed to activity developed during the democratic period. During the period of Franco regime, neither substantial improvement nor an alternative approach occurred in relation to the activity that had been developed before the Civil War. Furthermore, Franco regime experienced a lack of trained personnel and important loss of executives due to exile. What proved even harder to manage in the short term was the restoration of ties with foreign university centers devoted to the study and promotion of Spanish culture. In many cases, vacancies in this sector were appointed to Spanish teachers who were forced to leave their country for political reasons (Gómez-Escalonilla, 2003).

\section{THE ACTION OF CERVANTES INSTITUTE IN A DEMOCRATIC SPAIN}

The arrival of democracy in Spain mobilized increased initiatives in the field of cultural action despite the initial lack of a clear plan with objectives to achieve and means to use for their achievement. 1991 was a crucial year for the organization and implementation of the Spanish cultural action since then the Cervantes Institute (Instituto Cervantes, IC) was established. This memorandum was a successful completion of a longpending effort which was eventually supported by references to the activity of other foreign institutions of similar nature. The establishment of the Cervantes Institute (Instituto Cervantes, IC), which had been postponed for a long time, received particular importance in the wake of the action taken by Spain in 1992when Spain organized a series of important international events. In this way Spain wanted to highlight the potential of the country and its commitment to follow the path of modernization once a democratic political system was consolidated in the country.

The newly established Institute was involved in the promotion of teaching Spanish as a foreign language and the dissemination of Spanish culture. To this end, Cervantes Institute was merged with a set of mechanisms previously existing under the auspices of various ministries (mainly the Ministry of Foreign Affairs). Following the reform of Spain, Cervantes Institute exploited these mechanisms as its antennas in the world. As a legacy of the previous regime, the new organization had a strong position in Europe and limited presence in the Middle East and North Africa which was further decreased in the US and other African and Asian countries (Jevenois Acillona, 1996).

However, Cervantes Institute should still overcome organizational problems and problems related to illtrained teachers, it should establish a standardized teaching system of the Spanish language which should be adopted by Cervantes Institute and also other co-operating centers, it should organize a process for certifying knowledge of Spanish as a Foreign Language and also establish new libraries and documentation centers as well as a website for the promotion of services offered thus introducing new technologies to serve its objectives. Cervantes Institute also worked on acquiring accurate knowledge on the state of the Spanish language around the world and reaching native Spanish population in different countries and enjoying their support. At the same time, Cervantes Institute developed a series of cultural activities, which aimed to introduce a form of programming, to exploit resources available to the Institute, to cooperate with other national and foreign Institutes and to develop appropriate and efficient communication strategies with them (Herrera de la Muela, 2007). The work of Cervantes Institute received a multidimensional character. It utilized a great asset, i.e., the Spanish language, an element of outstanding significance since it connected all nations of Latin America and struggled to improve the image of a country with low productivity and people mainly interested in having fun and enjoying the sun and the sea.

The establishment of democracy in Spain, economic growth and the search for an international leading role were reinforced by Spain joining the European Union. In this way, the reform of a faltering foreign cultural policy and the formulation of a new policy that would be based on cooperation were supported. Since Spain joined the EU, Europe has become the preferred area for cultural promotion, given that cooperation with Latin America had already been established. Other attractive areas were North Africa in the context of the Spanish Mediterranean policy, the Middle East, where Spain wished to receive a role by participating in talks and negotiations in order to contribute to the efforts for peace, as well as countries of the Asia-Pacific region where in addition to existing ties with Philippines, Spain had a strong objective to strengthen trade links in the region. Relations with the US were maintained mainly in the field of scientific and technological exchange; however, as in other areas, many cultural activities were developed for the promotion of Spanish culture. It is worth noting that despite the fact that the state had been traditionally considered as the main 
source of cultural activity, at that point there was a clear turn towards a more active participation of civil society in cultural activity.

During the end of the 20th century and especially during the first decade of the 21st century, cultural action outside Spain received significant attention and was highly promoted together with the promotion of the image of the country, which was successfully upraised by the presence, diversity and complexity of Spanish culture (Gómez-Escalonilla, 2012).

\section{CONCLUDING REMARKS}

Spain, a country with strong and dynamic cultural elements recognized very early their outstanding importance. Cultural heritage was a tool which Spain could use and exploit. Despite the turbulent history of the country at a political and social level, and regardless of switching between dictatorial and democratic regimes, action at cultural level was never completely lost. Cultural action received particular attention during the prevalence of democracy after Franco's death and even more with the country's entry into the European family.

The development of the cultural policy of Spain did not always have the same character, but it always had the same purpose: to promote the country abroad, to restore a credible and stable standing of Spain in the international system. The exercise of cultural policy and the existence of cultural strategy passed through different stages depending on historical circumstances. There was a transition from a state-centric system, which gathered and controlled all forms of cultural activity, to unconstrained independent institutions and organizations focusing on highlighting and promoting the Spanish culture. Civil society also received an equally important position as citizens were recognized as the most important actors of the system.

Through the analysis and presentation of the historical narrative of Spain, it becomes apparent that Spain had realized, understood and applied the concept of the use of "soft power" much before 1990 when it was first formally introduced by the American Harvard professor, Joseph Nye. The concept of power can be distinguished in "soft power" and "hard power". According to Joseph Nye, soft power is defined as a form of power which one can use - without threats or any form of enforcement - to persuade others to pursue one's own objectives. Soft power essentially forms an implicit way of exercising power. Instead, hard power is based on the use of enforcement, mainly through military and economic power, in the form of incentives ("carrots") or threats ("sticks"). The use of soft power is an efficient, indirect way for a country to exercise power for achieving desired results in world politics by making other countries willing to support it, admire its values and culture and follow its examples.

According to Nye, soft power of a country is based on culture, political values and foreign policy, which constitute the three pillars of soft power. These three pillars are built on elements which include language, quality of academic education, historical monuments, but also issues such as quality of democracy, level of freedom, and more. Soft power essentially builds upon the way external actors view a country and, thus, can be considered as a measure of attraction. Soft power is highly important for modern states since if exercised successfully, soft power can upgrade the international profile of a country and promote an image of stability, strength and reliability.

In conclusion, the global system is characterized not only by dominance of geopolitical power and market forces, but also by a shift to elements that contribute to the enhancement of the image of the country, most important being the promotion of culture. Spain, undoubtedly, deserves a place among those countries that used soft power extensively and successfully in the past and continue to act this way.

\section{REFERENCE LIST}

Fernández L. S., Pérez D. R., Comellas J. L. y Andrés-Gallego J. (1991). Historia General de España y América, La época de Franco, Ed. Rialp, Madrid.

Gómez J. T. (1993). El régimen de Franco, 1936-1975: política y relaciones exteriores, UNED, Madrid.

Gómez-Escalonilla, L. D. (1992). Imperio de papel. Acción cultural y política exterior durante el primer franquismo, CSIC, Madrid. 
Gómez-Escalonilla, L. D. (1995). Las relaciones culturales de España en tiempo de crisis: de la II República a la Guerra Mundial, UNED, Madrid.

Gómez-Escalonilla, L. D. (2002). América como estímulo: regeneración nacional y tierra de oportunidades, CSIC, Madrid.

Gómez-Escalonilla, L. D. (2012). La acción cultural exterior de España: trayectoria reciente y retos pendientes, Ariel-Real Instituto Elcano, Barcelona.

Herrera de la Muela, I. (2007). La contribución del Instituto Cervantes a la promoción exterior de la cultura española e hispanoamericana: ¿actor o agente?, Instituto Cervantes, Madrid.

Jevenois Acillona, P. (1996). Los Centros Culturales y Educativos en el exterior, Ministerio de Asuntos Exteriores, Madrid.

Pérez Garzón J. S. (2000). La creación de la historia de España, Crítica, Barcelona

Redondo G. (1999).Política, cultura y sociedad en la España de Franco, Ed. Universidad de Navarra, Navarra.

Rodríguez A. N. (1993). Hispanoamericanismo, regeneración y defensa del prestigio nacional (1898-1931), Aieti/Síntesis/OEl, Madrid.

Rodríguez A. N. (2001). Orígenes y despliegue de la política cultural, L’ Harmattan, París. 